Heidi Hirvasoja-Korkee and Leena Holopainen, Department of Special Education, Philosophical Faculty, University of Eastern Finland; Asko Tolvanen, Department of Psychology, University of Jyväskylä Jukka Leskinen, Department of Behavioural Sciences, National Defence University, Finland.

\title{
THE RELATION BETWEEN FINNISH CONSCRIPTS' READING DIFFICULTIES (RD), COGNITIVE ABILITIES AND THE LENGTH OF SERVICE PERIOD
}

\begin{abstract}
In this study, the existence of reading difficulties (RD) among young adults and the relation between $R D$, cognitive abilities and length of service period were examined. The aim was to study the manifestation of reading difficulties with young adult males, the connection between different cognitive abilities and reading comprehension and decoding skills, and to determine whether the membership of different reading skills groups was related to the length of the service period, which is partly dependent on the scores of cognitive assessment in military service, Basic Test 1. The participants in this study $(N=1399)$ were Finnish adolescents (mean age 20 years, sd .61) participating in compulsory military service. Every Finnish male citizen is obligated to undergo military service and because $R D$ is more common in males than females, warfare becomes more technological and military training is increasingly based on written material that requires reading skills, it is very reasonable to study $R D$ with persons in military service. Results showed that reading difficulties persist into adulthood, but some regional differences were found, and reading difficulties (especially decoding difficulties) had only a minor direct connection to the length of the service period.
\end{abstract}

\section{Keywords}

Cognitive ability, conscript service, reading difficulty 


\section{Introduction}

This study is part of a broader project aimed at developing conscript service to take into better account conscripts with reading difficulties (RD) and attempting to prevent attrition from military service on educational basis. Every Finnish male citizen is liable for compulsory military service and women may volunteer for military service. An exemption order is permitted for expatriate dual citizens, Jehovah's Witnesses, persons with serious health issues, and civil servants (Salo, 2008). As warfare becomes more technological, depending on the branch and training path, military training is increasingly based on written teaching material that requires reading skills. Therefore, it is important to find ways of developing conscript training so that the capability of talented persons can be fully utilized despite their reading difficulties and to ensure that reading difficulties do not restrict conscripts training path. From adolescent's viewpoint, a successful conscript service period can be a positive experience and break possible exclusion. A positive service experience can reinforce the self-esteem of a conscript with $\mathrm{RD}$, giving them an opportunity to success in an educational environment as part of a positive learning experience, and encouraging a new attitude towards education. Compulsory conscript service reaches a large number of young adults $(99 \%$ of males and $1 \%$ of females), and therefore is an excellent opportunity to study the role of reading skills or difficulties during completion of the service.

Reading and spelling disabilities are language processing problems that primarily affect the ability to analyze and manipulate the sounds of spoken words, which creates problems in learning to read (Snowling, 2000). Reading difficulty (RD) is described as an inability to decode the phonological and morphological structure of the written language. It also refers to difficulties with accurate and/or fluent word recognition, decoding ability and spelling, and problems with reading comprehension, which can be a secondary consequence of decoding problems (Hudson, High, \& Otaiba, 2007; Lyon, Shaywitz, \& Shaywitz, 2003). Difficulties in reading comprehension cause problems in making logical connections among parts of a text, and therefore in understanding the structure of a story (Perfetti, Marron, \& Foltz, 1996; Stothard \& Hulme, 1996). Reading comprehension problems impede or slow down the acquisition of knowledge through reading - a function that is essential for academic study. In addition, 
reading comprehension problems can lead to reduced reading experience, which can impede vocabulary growth (Church, Fessler, \& Bender, 1998; Lyon et al., 2003) which, in turn, reduces understanding of texts.

It has also been shown that there are gender differences, that is, decoding problems are more common in males than females (Berninger, Nielsen, Abbott, Wijsman, \& Raskind, 2008; Liederman, Kantrowitz, \& Flannery, 2005; Savolainen, Ahonen, Aro, Tolvanen, \& Holopainen, 2008), and more males than females are classified as poor readers (decoding and reading comprehension difficulties) throughout grades 1-8 (Badian, 1999). However, these gender differences may not be as prevalent as previous research has suggested (Wheldall, 2010), namely poor comprehenders are typically identified in the later elementary school years, and the proportion of females to males increases at that time (Adlof, Catts, \& Lee, 2010).

Research has indicated that reading difficulty often persists into adulthood; typical problems in adulthood include a slow reading speed and phonetic spelling (Bruck, 1990). Although a number of studies have reported that intelligence quotient (IQ) does not have a significant relation with decoding difficulties (Kortteinen, Närhi, \& Ahonen 2009; Vellutino, Scanlon, \& Lyon, 2000; Torgensen \& Wagner, 1998), in the long term, RD may impair not only the development of linguistic abilities and reading skills, but also general cognitive ability. Initially, a minor reading problem could widen into a major cognitive, behavioural, or motivational problem; this process is known as the Matthew effect (Stanovich, 1986). In some studies (for example Fawcett, Nicolson, \& Maclagan, 2001) connection between reading skills and IQ has been found, when IQ tests typically also evaluated verbal abilities (Vellutino et al., 2000), but differences between those with reading difficulties and normal readers has usually not been explained by differences in IQ (Jiménez, Siegel, \& Lopez, 2003; Jiménez, Siegel, O'Shanahan, \& Ford, 2009).

In adolescence, RD may also cause secondary problems, such as learning difficulties, poor self-image, and low motivation in demanding learning situations. Therefore, students with RD usually choose shorter courses, drop out of school earlier, and choose "easier" school paths even though their other cognitive skills could provide for a longer educational path. There are also other challenges in adolescence concerning education and $\mathrm{RD}$ such as increasing demands, expectations, and requirements with regard to learning and studying and, in most cases, and at the same time, the cessation of help and support (Berninger et al., 2008; Zeffort \& Eden, 
2000). However, it has been shown that some adults with RD may have developed different kinds of learning strategies to compensate for RD (Wilson \& Lesaux, 2001) and are able to participate successfully in more challenging educational paths (Deacon, Parrila, \& Kirby, 2006).

The comorbidity of difficulties in reading, spelling and mathematics could also be seen as a major challenge in learning and school achievement (Levine \& Nourse, 1998; Lyon et al., 2003). Light and DeFries (1995) showed that most students (around 80\%) who have difficulties in reading have difficulties in mathematics in upper grades, even if their achievements in mathematics were average at the beginning of their school years. This finding could be due to the same kind of cognitive demands in mathematics and reading. Both sub-systems seem to require well-organized working memory and functioning of phonological loop (Baddeley, Gathercole, \& Papagno, 1998; Geary, 2004; Swanson, 2006). Another explanation is the theory of "generalist genes", which suggests that most genetic influences are more general than specific (Davies et al., 2008). Plomin and Kovas (2005) assumed that the genes that control the normal variation of development of abilities also influence the development of contemporary difficulties in mathematics and reading.

Military service duty in Finland begins at 18 years of age and lasts till the age of 60. Most conscripts begin their service at the age of 19 or 20. The duration of the Finnish conscript service is 180, 270 or 362 days depending on the training path. The length of service is determined by factors including the conscript's own choice and the results of the cognitive assessment made in the beginning of the service period. The first eight weeks involve basic training, after which conscripts choose from among three training paths: combatants training (180 days), special skills training (270 days), and non-commissioned officers (NCOs) or officers' training (362 days). The same training regime applies to voluntary female conscripts. Over $80 \%$ of conscripts complete the conscript service while 8$10 \%$ terminate the service prematurely. It has been shown that negative school and learning experiences and low motivation can be reasons for terminating the training period (Parkkola, 1999). It has also been shown that attrition increases the risk of marginalization (Salo, 2008), and psychosocial distress and accumulation of problems are shown among those men who are exempted from military service or fail to complete their service (Appelqvist-Schmidlechner, 2011; Appelqvist-Schmidlechner, Upanne, Henriksson, Parkkola \& Stengård, 2010). At the beginning of the service period, every conscript's cognitive abilities are assessed. Cognitive 
abilities are usually specified as receiving, acquiring and adapting information, solving problems, memory, and learning new skills. In reading comprehension, fluent reading and word recognition cognitive processes are needed to understand the phonological structure of written language, to receive, acquire and adapt information, to rapidly name phoneme and letters, to understand the vocabulary, and to use short- and long-term memory (Fletcher, Lyon, Fuchs, \& Barnes, 2009). The cognitive assessment in military service (=Basic test 1 ) is equivalent to other aptitude measures such as the Different Aptitude Test (DAT), the General Aptitude Test Battery (GATB) and the Armed Services Vocational Aptitude Battery (ASVAB). The results of this cognitive assessment have a major impact on conscripts' training path, particularly towards leadership training (NCOs or officers) meaning that if Basic Test 1 scores are low, conscripts possibilities going on to leadership training are low regardless of personal desire.

The main aim of this study is to find out how reading difficulties are connected to conscripts' cognitive levels and the length of the military service period.

Therefore, three research questions were formulated:

(1) What kinds of reading skills and difficulties can be found in young adults in conscript service?

(2) How are cognitive abilities connected to reading difficulties?

(3) How are reading difficulties and cognitive abilities connected to the length of service period?

\section{Methods}

\subsection{Participants}

The participants were conscripts (mean age 20) in the intake of January 2009. In January 2009 the reading comprehension and decoding data were collected in the North Karelia brigade (N=640) and in March 2009 in the Kainuu brigade ( $\mathrm{N}=1083)$. The Kainuu brigade is situated in the northern part of Finland and the North Karelia brigade is situated in the eastern part of Finland. There are some differences between brigades and their branches, both brigades are infantry (NCOS or reserve officers) and signal training. The bigger brigade, Kainuu, also includes field artillery (reserve officers, 
NCOs, or rank and file), and engineers (NCOs and reserve officers, and those with special duties, such as operators of machinery and drivers of special vehicles). The Kainuu brigade is also called the "readiness brigade" because it plans for immediate action in the case of a crisis. All conscripts participated voluntarily in the research (in North Karelia 28 did not come to testing and in Kainuu, 24). We asked the conscripts permission to use the results of measured cognitive ability tests (Basic Test 1) in our research and $81.9 \%$ in the North Karelia brigade ( $N=524: 523$ males, 1 female) and $80.8 \%$ in Kainuu brigade ( $\mathrm{N}=875$ : 862 males, 13 females) gave permission. The number of participants in this research was 1399 altogether.

\subsection{Procedure}

The tests were presented in the same order and with the same instructions to all participants. All testing was done in groups at the garrison areas. For group testing, conscripts were gathered together into classrooms (an average of 67, depending on the branch). Basic Test 1 was implemented by section leaders with consistent instructions. This session lasted approximately 90 minutes. After Basic Test 1, the Finnish dyslexia screening test for youth and adults was presented to the conscripts. The testing procedure of reading comprehension and decoding tests was carried out by three persons who were specially trained for the purpose. This session lasted approximately 40 minutes. Conscripts could decide whether all their test results could be used in this research, and conscripts who gave permission to use registration information about their military training were included in this research.

\subsection{Measures}

Reading comprehension and decoding. The assessment of reading skills was made with the Finnish dyslexia screening test for youth and adults, which is standardized for persons aged 15 and older (Holopainen, Kairaluoma, Nevala, Ahonen, \& Aro, 2004). In this study, three subtests were used: a reading comprehension test and two word reading tests. Although the test is standardized for equal numbers of males and females, in our data almost all the participants were male. However, the criteria for difficulties in reading were used as set in the standardized test.

The reading comprehension test includes a four-page story in which 52 words have been changed; the participants have to mark the changed words by underlining them. The changed words are in the same word class as the original, but will not conform to clauses or paragraphs, and can be 
inadequate in the context in many different ways. The test requires an ability of multi-level reading comprehension: understanding the storyline, finding irrelevant and wrong expressions, and constructing interpretations between inappropriate content and misleading information (Holopainen et al., 2004). The time limit for the reading comprehension test was 30 minutes. The test score was the total number $(\max 52)$ of correctly identified items. In this study, the Alpha score in the reading comprehension test was .91 in both brigades. The criteria for difficulties in reading comprehension was the $8 \%$ criteria level used in standardized tests and commonly thought to be very strict in other RD studies; the cut point was at 21 points, that is, the lowest $8 \%$ in the standard test. Both word reading tests contain 100 words each. The first task is to find misspellings; there is one mistake (one letter omitted or one wrong letter added) in each word. Participants mark spelling errors with a vertical line. The test time is 3 minutes and 30 seconds. The second task includes word chains in which the words have to be separated from each other with a vertical line. Words have been written together in four-word clusters without spaces between them. The time for this test is 1 minute and 30 seconds. Because of the time limits, success requires quick and accurate knowledge of words, understanding of correct spelling, recognition of word forms and meanings, and rich vocabulary (Holopainen et al., 2004). In this study, two word reading tests were combined to a sum variable and used as a sum variable of decoding. The sum score was the total number (100) of items marked/ separated correctly (Alpha $=.83$ in North Karelia and .82 in Kainuu). Moreover, in this test the criteria for difficulties in decoding was the $8 \%$ criteria level used in standardized tests and commonly thought to be very strict in other RD studies; the cut point was 40 points, that is, the lowest $8 \%$ in the standard test.

Cognitive abilities. Basic Test 1 consists of three tests of cognitive abilities. It measures the power of deduction of linguistic, numeric, and non-verbal abilities, and it can be used as measure of a person's general cognitive level. The test was developed following psychometric test principles of development and used only in the Finnish Defence Forces. The average reliability of Basic Test 1 is .79-83 (Nyman, 2007). In this study, alpha of Basic test 1 was .849 in North Karelia and .814 in Kainuu. Linguistic and numeric tests are based on factor analytical theories of intelligent abilities. The linguistic part contains four subtests: synonyms, similarities, classes and analogies. The numeric part also contains four subtests: number sequences, arithmetic, rules for calculating and analogies. The nonverbal part is a Raven's progressive matrices test to assess the conceptual power of deduction. All three tests include 40 exercises in order of difficulty. These 
three tests of mental abilities together form a P1-value that is equivalent to a G-factor, which measures universal talent (Nyman 2007). In this study, instead of using P1-value, raw scores in each test of mental abilities were used. Raw scores were combined to three sum variables: the sum variable of linguistic abilities (alpha $=.89$ in North Karelia and .90 in Kainuu); the sum variable of numeric abilities (alpha $=.87$ in North Karelia and .90 in Kainuu); and the sum variable of nonverbal abilities (alpha $=.82$ in North Karelia and .84 in Kainuu).

Length of the service period. Length of the service period is the time conscripts serve, which is 180,270 or 365 days ( $1=362$ days, $2=270$ days, $3=180$ days).

\subsection{Statistical Analysis}

When the reading comprehension and decoding tests were examined, differences in reading skills between garrisons were found. To estimate the statistically significant difference between the results of reading tests, an independent samples t-test was performed.

Cohen's d effect size analysis is used as a complementary method to estimate whether there is a real difference between variables. The purpose is to exclude the effects of the sample size such as statistically significant results due to a large sample, and to facilitate the mutual comparison among different sized samples. In this study, Cohen's d effect size analysis was conducted to find the difference between garrisons in reading comprehension and decoding tests and to find out possible significant regional differences in reading comprehension and decoding skills. The Cohen's d -value limit used was .50. T-test; Cohen's d effect size analysis was also performed on the subtests of Basic Test 1 to study differences in cognitive abilities. Correlations were measured to study the connection between the Finnish dyslexia screening test for youth and adults and Basic Test 1 .

Crosstabulation with adjusted residuals analysis was used to assess differences between groups of abnormal distributions or ordinary scale variables. In this study, crosstabulation was used to study the reading difficulty percentages between brigades and standard data. The limit value used for statistically significant results of the Pearson Chi-Square was .05. Adjusted residuals were used to find out if percentage values were statistically significantly consistent. A negative value of the adjusted residual meant that the percentage was smaller than expected, and a positive value of 
the adjusted residual meant that the percentage was larger than expected. If the absolute value of the adjusted residual was greater than 2 , it was considered statistically significant $(\mathrm{p}<.05)$.

Multinomial logistic regression analysis was used to find out how conscripts cognitive abilities composed in four different types of reading skills based on limit scores of reading comprehension and decoding tests in the standardized reading test. Multinomial logistic regression analysis was also used to study how cognitive abilities and reading difficulties were connected to length of service period.

\section{Results}

Firstly, we wanted to see what kind of reading skills were found among young adults (see Table 1). Because we did not hypothesize differences between the reading skills of the two brigades, the brigades were first analysed together, but after comparing brigades, we found differences in reading skills. According to the results of the independent samples t-test the garrisons differed significantly both in the reading comprehension test $(\mathrm{t}$ $(1002)=-3.36, \mathrm{p}<.001 ;$ Cohen's $\mathrm{d}=.56)$ and the decoding test $(\mathrm{t}(1395)=$ $1.99, \mathrm{p}<.047$; Cohen's $\mathrm{d}=.62)$. The conscripts in the Kainuu brigade $(\mathrm{K})$ were significantly better than the conscripts in the North Karelia (NK) brigade. Due to these statistically significant differences, the garrisons were analyzed separately in further analyses (see Table 2).

\begin{tabular}{|c|c|c|c|c|c|}
\hline \multicolumn{6}{|c|}{$\begin{array}{l}\text { Table } 1 \\
\text { Frequencies }(N), \text { lowest (Min) and highest (Max) scores, means }(M) \text {, standard deviations (SD), } \\
\text { in reading comprehension test, decoding test and subtests of Basic Test } 1\end{array}$} \\
\hline$\overline{\text { Test }}$ & $\mathrm{N}$ & Min & $\operatorname{Max}$ & $\bar{M}$ & SD \\
\hline Reading comprehension & 1398 & 1 & 51 & 37.61 & 8.70 \\
\hline$\overline{\text { Decoding }}$ & 1397 & 9 & 100 & 60.85 & 16.18 \\
\hline Linguistic abilities in Basic Test 1 & 1381 & 0 & 38 & 21.41 & 6.36 \\
\hline Numeric abilities in Basic Test 1 & 1381 & 0 & 40 & 19.29 & 7.05 \\
\hline Nonverbal abilities in Basic Test 1 & 1381 & 3 & 38 & 26.42 & 5.80 \\
\hline
\end{tabular}


Because the standardized reading test (Holopainen et al., 2004) is standardized with data that have equal numbers of males and females, the conscripts' performances in reading comprehension and decoding tests were compared to the performances of men in the standardized test. An interesting result was that the conscripts' mean values of the reading comprehension test in both brigades ( $\mathrm{NK} \mathrm{M}=36.58, \mathrm{SD}=9.29 ; \mathrm{K} \mathrm{M}=38.23, \mathrm{SD}=8.27$ ) were better than in the standardized test $(\mathrm{M}=33.95, \mathrm{SD}=10.26)$. In the decoding test, the conscripts' mean scores in both brigades (NK M $=59.74, \mathrm{SD}=$ $15.79 ; \mathrm{K} \mathrm{M}=61.52, \mathrm{SD}=16.39$ ) were lower than in the standardized test $(\mathrm{M}=61.79, \mathrm{SD}=18.05)$.

\section{Table 2}

Frequencies $(N)$, lowest (Min) and highest (Max) scores, means (M), standard deviations (SD), in reading comprehension test, decoding test and subtests of Basic Cognitive Test 1 and T-tests, $P$-values and Cohen's $d$-values between brigade of Kainuu and brigade of North Karelia.

\begin{tabular}{|c|c|c|c|c|c|c|c|c|c|c|}
\hline$\overline{\text { Test }}$ & Data & $\mathrm{N}$ & Min & Max & $\mathrm{M}$ & SD & T-test & $\overline{D F}$ & P-value & Cohen's $d$ \\
\hline \multirow[t]{2}{*}{ Reading compreh. } & NK & 524 & 1 & 50 & 36.58 & 9.29 & \multirow[t]{2}{*}{-3.362} & \multirow[t]{2}{*}{1002} & \multirow[t]{2}{*}{.001} & \multirow[t]{2}{*}{0.56} \\
\hline & $\overline{\mathrm{K}}$ & 874 & 1 & 51 & 38.23 & 8.27 & & & & \\
\hline \multirow[t]{2}{*}{ Decoding } & NK & 524 & 16 & 100 & 59.74 & 15.79 & \multirow[t]{2}{*}{-1.986} & \multirow[t]{2}{*}{1395} & \multirow[t]{2}{*}{.047} & \multirow[t]{2}{*}{0.62} \\
\hline & $\overline{\mathrm{K}}$ & 873 & 9 & 100 & 61.52 & 16.39 & & & & \\
\hline \multirow{2}{*}{$\begin{array}{l}\text { Linguistic abilities } \\
\text { in Basic Test } 1\end{array}$} & NK & 517 & 1 & 38 & 21.58 & 6.55 & \multirow[t]{2}{*}{.768} & \multirow[t]{2}{*}{1379} & \multirow[t]{2}{*}{.443} & \multirow[t]{2}{*}{-0.11} \\
\hline & $\overline{\mathrm{K}}$ & 864 & 0 & 38 & 21.31 & 6.25 & & & & \\
\hline \multirow{2}{*}{$\begin{array}{l}\text { Numeric abilities in } \\
\text { Basic Test } 1\end{array}$} & NK & 517 & 0 & 40 & 18.95 & 7.03 & \multirow[t]{2}{*}{-1.397} & \multirow[t]{2}{*}{1379} & \multirow[t]{2}{*}{.163} & \multirow[t]{2}{*}{0.21} \\
\hline & $\overline{\mathrm{K}}$ & 864 & 0 & 40 & 19.50 & 7.06 & & & & \\
\hline \multirow{2}{*}{$\begin{array}{l}\text { Nonverbal abilities } \\
\text { in Basic Test } 1\end{array}$} & NK & 517 & 3 & 38 & 25.93 & 6.22 & \multirow[t]{2}{*}{-2.366} & \multirow[t]{2}{*}{986} & \multirow[t]{2}{*}{.018} & \multirow[t]{2}{*}{0.32} \\
\hline & $\overline{\mathrm{K}}$ & 864 & 4 & 38 & 26.17 & 5.52 & & & & \\
\hline
\end{tabular}

Note: NK North Karelia Brigade, K Kainuu Brigade

The conscripts' performance in the cognitive Basic Test 1 between garrisons was also studied by independent samples t-test and Cohen's d effect size analysis (see Table 2). There were no statistically significant differences between garrisons in the test of numeric abilities $(\mathrm{t}(1379)=-1.397, \mathrm{p}<$ .163 , Cohen's $d=0.21)$ or in the test of linguistic abilities $(\mathrm{t}(1379)=.768$, $\mathrm{p}<.443$, Cohen's $\mathrm{d}=-0.11)$. Only the test of non-verbal abilities showed statistically significant differences $(\mathrm{t}(986)=-2.366, \mathrm{p}<.018$, Cohen's $\mathrm{d}=$ 0.32 ) between garrisons so that conscripts in the Kainuu brigade got 
significantly higher scores than the conscripts in the North Karelia brigade but Cohen's d was not very strong.

With the first research question we wanted to know how many conscripts in each brigade would have difficulties in reading comprehension and/ or decoding. In this study, the cut point in the reading comprehension test was 21 points (the lowest $8 \%$ in the standardized test) and 40 points (the lowest $8 \%$ in the standardized test) in the decoding test. In the North Karelia brigade, the percentage of conscripts with reading comprehension difficulties was $7.25 \%$, and $4.92 \%$ in the Kainuu brigade. In decoding difficulties, the percentages were $10.50 \%$ and $10.65 \%$, respectively. We compared these results to standard data by using cross-tabulation and adjusted residuals in order to find out if these differences were statistically significant. Results showed that, in the decoding test percentage value in Kainuu brigade was statistically significantly higher than expected $\left(\chi^{2}=4.766, \mathrm{df}=1, \mathrm{p}<.03\right.$, adjusted residual 2.2), but not in the North Karelia brigade $\left(\chi^{2}=3.067, \mathrm{df}=1\right.$, $\mathrm{p}<.08$, adjusted residual 1.8). In reading comprehension, results showed that, in the Kainuu brigade the percentage value was statistically significantly lower than expected $\left(\chi^{2}=8.450, \mathrm{df}=1, \mathrm{p}<.004\right.$, adjusted residual -2.9) but in the North Karelia brigade the percentage value did not differ statistically significantly from standard data $\left(\chi^{2}=.325, \mathrm{df}=1, \mathrm{p}<.57\right.$, adjusted residual -.6).

We also wanted to know how many of the conscripts had difficulties both in reading comprehension and decoding. To acquire this information, a more specific four-class RD variable was formulated to separate poor readers, meaning conscripts who had difficulties both in reading comprehension and decoding, from those who have only reading comprehension or decoding difficulties. In the North Karelia brigade, the percentage of conscripts with difficulties only in reading comprehension was $5.2 \%$, conscripts with difficulties only in decoding was $8.4 \%$, poor readers was $2.2 \%$ and conscripts without difficulties $84.4 \%$. In the Kainuu brigade, the percentage of conscripts with difficulties in reading comprehension only was $2.2 \%$, the percentage of conscripts with difficulties in decoding only was $7.9 \%$, the percentage of poor readers was $2.7 \%$ and the percentage of conscripts without difficulties $86.9 \%$ (see Table 3). 


\section{Table 3}

Frequency $(N)$ and percentiles (\%) in different kind of reading difficulties groups: conscripts with difficulties only in reading comprehension, conscripts with difficulties only in decoding, poor readers meaning conscripts with difficulties both in reading comprehension and decoding, and conscripts without difficulties in both brigades.

\begin{tabular}{llll}
\hline Reading Difficulties Groups & Data & N & $\%$ \\
\hline Difficulties only in reading comprehension & North Karelia & 27 & 5.2 \\
\cline { 2 - 4 } & Kainuu & 19 & 2.2 \\
\hline Difficulties only in decoding & North Karelia & 44 & 8.4 \\
\cline { 2 - 4 } & Kainuu & 69 & 7.9 \\
\hline Poor readers & North Karelia & 11 & 2.1 \\
\cline { 2 - 4 } & Kainuu & 24 & 2.7 \\
\hline Without difficulties & North Karelia & 442 & 84.4 \\
\cline { 2 - 4 } & Kainuu & 760 & 86.9 \\
\hline
\end{tabular}

In order to answer the second research question, first the correlations between the two reading tests and subtests of cognitive tests were examined (see Table 4). Correlations were analysed from both brigades together because there was no reason to doubt differences between results or connections, and after comparing brigades no differences were found. Correlations between these results were very much the same in both brigades, which indicated that the phenomenon between these measured abilities is quite stable.

\section{Table 4}

Pearson's correlations between the reading comprehension and decoding tests, and the subtests of linguistic, numeric and nonverbal abilities of Basic Test 1.

\begin{tabular}{llll}
\hline Measures & $\begin{array}{l}\text { Linguistic } \\
\text { abilities }\end{array}$ & $\begin{array}{l}\text { Numeric } \\
\text { abilities }\end{array}$ & $\begin{array}{l}\text { Nonverbal } \\
\text { abilities }\end{array}$ \\
\hline Reading comprehension & $.477^{* *}$ & $.395^{* *}$ & $.372^{* *}$ \\
\hline Decoding & $.473^{* *}$ & $.463^{* *}$ & $.305^{* *}$ \\
\hline$* * \mathrm{p}<.01$ & & &
\end{tabular}

Furthermore, multinomial regression analysis was selected to study how conscripts cognitive abilities were related to their reading difficulties in the North Karelia (NK) brigade and the Kainuu (K) brigade (see Table 5). At first we studied the relationship between conscripts cognitive abilities and reading difficulties. We used categorical RD variable (reading difficulties- 
no reading difficulties) and all three cognitive abilities subtests as covariates. The used criteria for conscripts with reading difficulties were $8 \%$ criteria level in reading comprehension and decoding tests (meaning the lowest $8 \%$ in the standard test). Results showed that in both brigades cognitive abilities did explain conscripts dividing into $\mathrm{RD}$ group $\left(\mathrm{NK} \chi^{2}=92.847, \mathrm{df}=3, \mathrm{p}<.001\right.$, Nagelkerke Pseudo $\mathrm{R}^{2}=.283 ; \mathrm{K} \chi^{2}=153.315, \mathrm{df}=3, \mathrm{p}<.001$, Nagelkerke Pseudo $\mathrm{R}^{2}=.303$ ) although the coefficient of determinations were not very strong, and the nonverbal abilities did not have a statistically significant effect on RD in Kainuu ( $\left.\chi^{2}=1.323, \mathrm{df}=1, \mathrm{p}=.250\right)$.

Secondly, we wanted to find out the relationships between three different cognitive abilities and four different types of reading difficulty (see Table 5). Results showed that cognitive abilities did explain conscripts different RD types in both brigades ( $\mathrm{NK} \chi^{2}=115.089, \mathrm{df}=9, \mathrm{p}<.001$, Nagelkerke Pseudo $\mathrm{R}^{2}=.289 ; \mathrm{K} \chi^{2}=166.272, \mathrm{df}=9, \mathrm{p}<.001$, Nagelkerke Pseudo $\left.\mathrm{R}^{2}=.275\right)$ although coefficient of determinations were not very strong. Linguistic abilities $\left(\chi^{2}=34.055, \mathrm{df}=3, \mathrm{p}<.001\right)$, numeric abilities $\left(\chi^{2}=13.448, \mathrm{df}=3, \mathrm{p}=.004\right)$ and nonverbal abilities $\left(\chi^{2}=30.601, \mathrm{df}=3, \mathrm{p}<.001\right)$ had statistically significant effect on RD types in North Karelia. In Kainuu, linguistic abilities $\left(\chi^{2}=40.334, \mathrm{df}=3, \mathrm{p}<.001\right)$ and numeric abilities $\left(\chi^{2}=9.385, \mathrm{df}=3, \mathrm{p}=.025\right) \mathrm{did}$ have statistically significant effect on RD types but nonverbal abilities $\left(\chi^{2}=6.036, \mathrm{df}=3, \mathrm{p}=.110\right)$ did not. When used conscripts without difficulties as references class, linguistic abilities had the strongest effect on poor readers $(\mathrm{NK} \mathrm{p}<.001, \mathrm{OR}=.672 ; \mathrm{K} \mathrm{p}<.001, \mathrm{OR}=.804)$, difficulties in decoding $(\mathrm{NK} \mathrm{p}=.012, \mathrm{OR}=.908 ; \mathrm{K} \mathrm{p}<.001, \mathrm{OR}=.867)$, and difficulties in reading comprehension $(\mathrm{NK} \mathrm{p}=.002, \mathrm{OR}=.864 ; \mathrm{K} \mathrm{p}=.032$, $\mathrm{OR}=.889)$. Numeric abilities had a statistically significant effect on difficulties in decoding (NK $\mathrm{p}<.001, \mathrm{OR}=.837 ; \mathrm{K} \mathrm{p}=.006, \mathrm{OR}=.928$ ) and poor readers ( $\mathrm{NK} \mathrm{p}=.003$, $\mathrm{OR}=.729)$. Nonverbal abilities had an effect on poor readers $(\mathrm{NK} \mathrm{p}=.003$, $\mathrm{OR}=.1 .300)$ and difficulties in decoding $(\mathrm{K} \mathrm{p}=.05, \mathrm{OR}=.901)$. 


\section{Table 5}

Results of the multinomial logistic regression analyses with cognitive abilities connections to reading difficulties in both brigades.

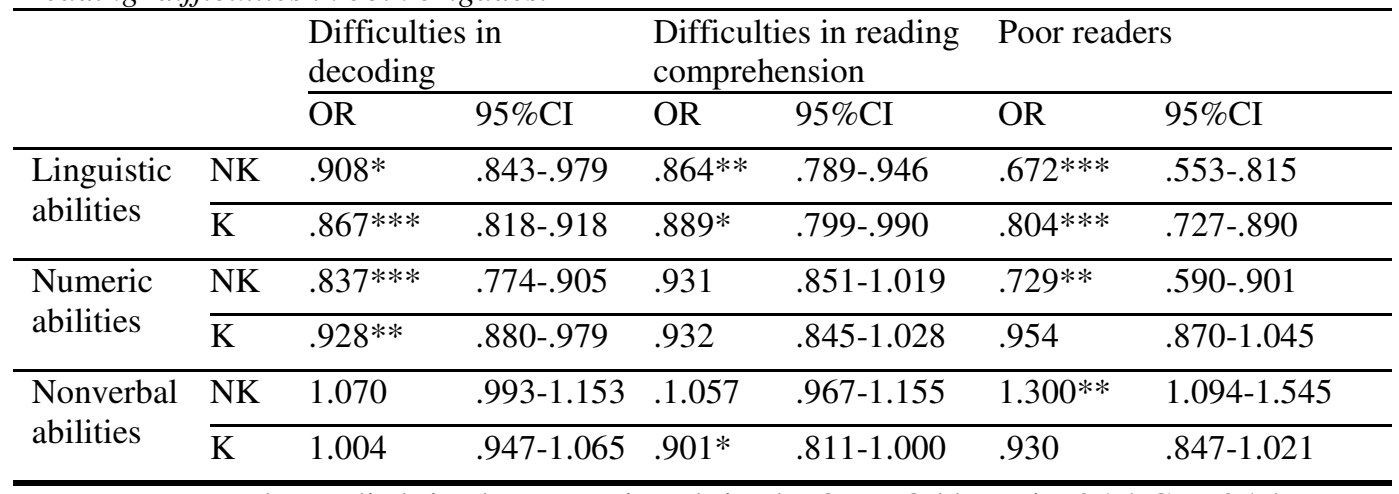

Notes: NK = North Karelia brigade. K = Kainuu brigade. OR = Odds Ratio. 95\% CI = 95\% Confidence interval. $* \mathrm{p}<.05, * * \mathrm{p}<.01$ and $* * * \mathrm{p}<.001$. Without difficulties class as reference category.

Thirdly, we wanted to see how reading comprehension or decoding difficulties were related to the length of the service period (see Table 6). Multinomial regression analysis was also used here. The results showed that decoding difficulties had a statistically significant connection with the length of the service period in the 270 days long service period ( $\mathrm{NK} \mathrm{p}=.014$, $\mathrm{OR}=.1 .016$ ) and in the longest service period ( $\mathrm{NK} \mathrm{p}=.014$, $\mathrm{OR}=.984)$. When comparing the 362 days long and 270 days long service periods, conscripts with decoding difficulties were more likely to end up on the 270 days long service period.

\section{Discussion}

The major aims of the study were to find out how reading difficulties would manifest themselves in Finnish conscripts, how cognitive abilities are connected to reading skills and difficulties and how different reading difficulties would be related to conscripts' chances to choose the length of service period. These questions were raised because as warfare becomes more technological military training is increasingly based on written teaching material that requires fast and accurate reading skills. Moreover, in modern society, even mild reading and writing problems can hamper the pursuit of personal, educational and vocational goals. Hence, it is important to find ways of developing conscript training so that the capability of 


\begin{tabular}{|c|c|c|c|c|c|c|c|c|}
\hline \multicolumn{9}{|c|}{$\begin{array}{l}\text { Results of the multinomial logistic regression analyses of the connection between reading } \\
\text { difficulties and length of the service period in both brigades. }\end{array}$} \\
\hline & & & \multicolumn{2}{|l|}{180 days } & \multicolumn{2}{|l|}{270 days } & \multicolumn{2}{|l|}{362 days } \\
\hline & & & $\overline{\mathrm{OR}}$ & $95 \% \mathrm{CI}$ & OR & $95 \% \mathrm{CI}$ & OR & $95 \% \mathrm{CI}$ \\
\hline \multirow{10}{*}{$\begin{array}{l}362 \\
\text { days }\end{array}$} & NK & Linguistic abilities & .978 & $.932-1.026$ & .986 & $.915-1.062$ & & \\
\hline & & Numeric abilities & .964 & $.923-1.007$ & .935 & $.872-1.002$ & & \\
\hline & & Nonverbal abilities & $.916^{* * * *}$ & $.870-.965$ & .969 & $.893-1.051$ & & \\
\hline & & $\overline{\text { Decoding }}$ & 1.007 & $.999-1.016$ & $1.016^{*}$ & $1.003-1.029$ & & \\
\hline & & Reading compreh. & .985 & $.960-1.012$ & 1.033 & $.983-1.085$ & & \\
\hline & $\mathrm{K}$ & Linguistic abilities & $.907 * * *$ & $.875-.941$ & 1.025 & $.952-1.103$ & & \\
\hline & & Numeric abilities & 1.015 & $.984-1.047$ & .987 & $.927-1.051$ & & \\
\hline & & Nonverbal abilities & $.930 * * *$ & $.894-.966$ & .937 & $.864-1.015$ & & \\
\hline & & $\overline{\text { Decoding }}$ & 1.006 & $1.000-1.011$ & 1.009 & $.998-1.021$ & & \\
\hline & & Reading compreh. & .996 & $.975-1.019$ & 1.048 & $.988-1.112$ & & \\
\hline \multirow{10}{*}{$\begin{array}{l}270 \\
\text { days }\end{array}$} & NK & Linguistic abilities & .992 & $.924-1.065$ & & & 1.014 & $.941-1.092$ \\
\hline & & Numeric abilities & 1.031 & $.965-1.103$ & & & 1.070 & $.998-1.147$ \\
\hline & & Nonverbal abilities & .946 & $.876-1.021$ & & & 1.032 & $.951-1.120$ \\
\hline & & Decoding & .992 & $.980-1.003$ & & & $.984^{*}$ & $.972-.997$ \\
\hline & & Reading compreh. & .954 & $.910-1.000$ & & & .968 & $.922-1.017$ \\
\hline & $\mathrm{K}$ & Linguistic abilities & $\begin{array}{l}.885^{* *} \\
*\end{array}$ & $.822-.954$ & & & .976 & 1.050 \\
\hline & & Numeric abilities & 1.028 & $.965-1.095$ & & & $\overline{1.013}$ & 1.079 \\
\hline & & Nonverbal abilities & .992 & $.916-1.076$ & & & 1.068 & 1.158 \\
\hline & & Decoding & .996 & $.985-1.008$ & & & .991 & 1.002 \\
\hline & & Reading compreh. & .951 & $.897-1.008$ & & & .954 & 1.012 \\
\hline \multirow{10}{*}{$\begin{array}{l}180 \\
\text { days }\end{array}$} & NK & Linguistic abilities & & & 1.008 & $.939-1.083$ & 1.022 & $.975-1.073$ \\
\hline & & Numeric abilities & & & .970 & $.907-1.037$ & 1.037 & $.993-1.083$ \\
\hline & & Nonverbal abilities & & & 1.057 & $.980-1.141$ & $1.091 * * *$ & $1.037-1.149$ \\
\hline & & $\overline{\text { Decoding }}$ & & & 1.009 & $.997-1.021$ & .993 & $.985-1.001$ \\
\hline & & $\overline{\text { Reading comprehension }}$ & & & 1.048 & $1.00-1.099$ & 1.015 & $.989-1.042$ \\
\hline & $\mathrm{K}$ & Linguistic abilities & & & $\overline{1.130 * * *}$ & $1.049-1.217$ & $1.102 * * *$ & $1.063-1.143$ \\
\hline & & Numeric abilities & & & .973 & $.913-1.037$ & .985 & $.955-1.016$ \\
\hline & & Nonverbal abilities & & & 1.008 & $.930-1.092$ & $1.076^{* * *}$ & $1.035-1.119$ \\
\hline & & Decoding & & & 1.004 & $.992-1.015$ & .994 & $.989-1.000$ \\
\hline & & $\overline{\text { Reading comprehension }}$ & & & 1.052 & $.992-1.115$ & 1.004 & $.982-1.026$ \\
\hline
\end{tabular}

Notes: As in Table 5. Reference categories are shown on the left. 
persons can be fully utilized, so that conscripts service could be a positive experience and break the vicious circle of educational disappointment, despite an individual's reading difficulties. The first main result was that reading difficulties occurred among conscripts, and surprisingly, when studying reading skills, in both reading tests (reading comprehension and decoding) the conscripts in the Kainuu brigade performed significantly better than the conscripts in the North Karelia brigade. Based on reading and decoding tests, four theoretically based reading skills types were formed, and discovered that different cognitive abilities had their own relation to reading difficulties. The results showed also that reading difficulties had only a weak connection to the length of service period. These results will be discussed in detail below.

Firstly, we wanted to find out the kind of reading skills and difficulties that could be found in young adults in two different brigades situated in different areas in Finland. The participants in this study were on average around 20 years old. It has been shown that, while reading difficulties persist at the group level into adulthood, adults nevertheless show large individual variation in the development of reading and spelling skills, as well as coping with problems in developing these skills with a varying degree of success (Goldberg, Higgins, Raskind \& Herman, 2003; McNulty, 2003). In languages such as Finnish, reading problems in adolescence and adulthood are often depicted as reading fluency problems (Lyytinen et al., 2005; Vellutino et al., 2004; Wimmer, Mayringer \& Landerl, 1998). Reading difficulties in everyday life can be stressful, because the demand for the rapid mastery of reading skills and dependence on the information obtained from printed and electronic sources has become increasingly important. Also in military service and in the army, as warfare becomes increasingly technological, competent reading and comprehension skills become more and more necessary (Salo, 2008; Zeffiro \& Eden, 2000). The fluency problems can also limit the amount of text read during leisure time. In this study, difficulties in decoding and reading comprehension occurred both separately and overlapping, which confirms the findings from other studies that reading difficulties often persist into adulthood (Bruck, 1990). The decoding test used in this study requires quick and accurate knowledge of words, understanding of correct spelling, recognition of word forms and meanings, and a rich vocabulary. The reading comprehension test used here requires understanding of the storyline, finding irrelevant and wrong expressions, and constructing interpretation between inappropriate content and misleading information (Holopainen, et al., 2004). These problems can 
be due to slow and inaccurate decoding, which affect motivation, but they are also part of a linguistic comprehension problem that impedes the acquisition of knowledge through reading (Berninger, et al., 2008). In military service or in other educational situations where actions and decisions should be made based on spoken language, this kind of linguistic problem is especially detrimental to the functioning and progress of the individual. People can also have difficultiy speech and organizing their thoughts, which creates problems in understanding and in organizing their thought on paper. They can also have difficulty with language processing and connection between words and the ideas they represent.

According to the results, the brigades differed significantly, both in the reading comprehension test and the decoding test, that is, the conscripts in the Kainuu brigade were significantly better than the conscripts in the North Karelia brigade. It is known that the conscripts that serve in the North Karelia brigade come mainly from the North Karelia area (48.4\%), the EteläSavo Region (27.3\%) and the Pohjois-Savo Region (17.3,\%). Conscripts in the Kainuu brigade come mainly from Ostrobothnia (34.4\%), the PohjoisSavo Region (20.9\%) and North Ostrobothnia (18.5\%). Only $12.5 \%$ of conscripts in the Kainuu brigade come from the Kainuu area. When the Finnish dyslexia screening test (Holopainen, et al. 2004) was standardized, data was collected from different parts of Finland, and the lowest reading results came from North Karelia. Therefore, the difference in reading tests between the brigades were in line with the results shown in the standardization of the reading test used in this study (Holopainen, et al., 2004). The explanations for this difference could also be found in the socioeconomic background or methods of teaching reading in schools, but these factors were not examined in this study. This difference is very interesting and the backgrounds of it need to be studied in the future.

Our study was in line with previous research, showing that, although some adolescents suffer from reading difficulties, those who have only decoding difficulties or only reading comprehension difficulties, do not differ from their peers in overall cognitive abilities (Fawcett, et al., 2001; Hatcher, Snowling, \& Griffiths, 2002). Moreover, conscripts' nonverbal abilities did not have any significant connection to decoding or reading comprehension difficulties, when the difficulties were not overlapping.

Because there were differences in the results of reading tests between the two brigades, the cognitive abilities of the conscripts were also compared between the two brigades. In the results of non-verbal abilities tests, a 
statistically significant difference between brigades was found, showing that the conscripts in the Kainuu brigade performed better, although the effect size was not strong. One explanation for this difference can be found in the differences between the brigades. The bigger brigade, Kainuu, includes field artillery (reserve officers, non-commissioned officers, or rank and file), and engineers (non-commissioned officers and reserve officers, and those with special duties, such as operators of machinery and drivers of special vehicles) and is also called the "readiness brigade" because it plans for immediate action in the case of crisis. Maybe this all affected conscripts' motivation, and thereby increased their satisfaction and willingness to serve there.

The third main objective of this study was to examine how cognitive abilities are connected to reading skills and how the difficulties in reading are connected to the length of military service. In both brigades, we formed four theoretically based reading skills groups. Our special interest was in groups that have problems with reading comprehension and/ or decoding. In common with some past studies (for example, Fawcett et al., 2001) connection between cognitive abilities (linguistic, numeric and nonverbal abilities) and reading difficulties (reading comprehension and decoding) were found in the poor readers' group, where the participants had problems both with reading comprehension skills and decoding skills, but only in North Karelia. Also, according to some other studies (for example, Light \& DeFries, 1995) and contrary to some other studies (Kortteinen et al. 2009; Vellutino et al. 2000; Torgensen \& Wagner 1998), a connection was found between numeric abilities and decoding difficulties. The causal relation between reading difficulties and cognitive abilities in the poor readers' group cannot be shown through the analytical method used here. In the poor readers' group, there was a connection between reading tests and the numeric part of Basic Test 1 . The same connection was also found between numeric abilities and decoding. The same comorbidity between reading difficulties and mathematical difficulties has been shown in earlier studies (Levine \& Nourse, 1998; Lyon et al., 2003). The comorbidity of difficulties is often a challenge in learning situations and might also cause secondary problems such as a lack of motivation and low self-esteem (Stanovich, 1986), and it has been shown that diverse problems are common among conscripts who terminate their service prematurely (Appelqvist et al., 2010). Previous studies (for example, Kortteinen et al., 2009; Vellutino et al., 2000; Torgensen \& Wagner, 1998) have shown that IQ is not significantly related to specific reading disabilities, but in the long term, RD may impair the development of other cognitive abilities, and therefore can affect general 
cognitive ability (Stanovich, 1986). Moreover, problems in cognitive abilities overall define poverty of learning skills (Fletcher, Lyon, Fuchs, \& Barnes, 2009), and problems in this area can affect motivation in learning and especially learning by reading. However, it has been shown that some adults with RD may develop compensative strategies for coping in different situations (Wilson \& Lesaux, 2001), and military service might offer a more functional training path.

Because the length of the conscript service (after six months or 180 days) is partly dependent on cognitive abilities (Basic Test 1), we wanted to see whether reading skills were related to length of service period. We found that reading difficulties (reading comprehension or decoding) did not in themselves have strong implications for the length of service, at least not for the shortest training path, meaning that reading difficulties do not rule out training path options in conscripts service, but results indicate that the possibilities of training paths in conscript service are potentially slightly limited for conscripts with decoding difficulties. Like adolescents with RD in school (Levine \& Nourse, 1998; Lyon et al., 2003), in conscript service, it can be possible that young adults with reading difficulties may choose or are forced to choose less demanding training paths in order to keep up motivation, and academic self concept.

The present study utilized the data collected in two brigades in Finland. Although there were almost 1400 participants in this study, some limitations need to be considered with regard to interpretation of the findings. Firstly, the sample consisted mainly in male participants, and caution should therefore be exercised in generalizing and grouping the results together with results from reading tests that have been standardized with data collected from both males and females. Secondly, owing to the large sample size, it was possible to use only a screening test in large groups for testing reading and cognitive abilities, so some situational, motivational or emotional effects could have influenced results, and individual testing would be more reliable. Thirdly, there are 15 brigade-level units in the Finnish army, and the Kainuu brigade the so-called readiness brigade, which could affect conscripts' motivation, and thereby increase their satisfaction and willingness in service. Finally, in the future, it will be necessary to use a structural equation path model to analyze the relations of reading difficulties and cognitive abilities in conscripts' performance and its connection to attrition. 


\section{References}

Adlof, S. M., Catts, H. W., \& Lee, J. (2010). Kindergarten predictors of second versus eighth grade reading comprehension impairments. Journal of Learning Disabilities, 43(4), 332-345.

Appelqvist-Schmidlechner. (2011). Time Out! Getting Life Back On Track. A psychosocial support programme targeted at young men exempted from compulsory military or civil service. Acta Universitatis Tamperensis, 1653. Tampere University Press.

Appelqvist-Schmidlechner, Upanne, Henriksson, Parkkola \& Stengård. (2010). Young men exempted from compulsory military service or civil service in Finland - A group of men in need of psychosocial support? Scandinavian journal of public Health, 0 , $1-9$.

Berninger, V. W., Nielsen, K., Abbott, R. D., Wijsman, E., \& Raskind, W. (2008). Gender differences in severity of writing and reading disabilities. Journal of School Psychology, 46, 151-172.

Braze, D., Tabor, W., Shnakweiler, D. P., \& Mencl W. E. (2007). Speaking up for vocabulary: Reading skill differences in young adults. Journal of Learning Disabilities, 40(3), 226-243.

Deacon, H. S., Parrila, R., \& Kirby, J. R. (2006). Processing of derived forms in high-functioning dyslexics. Annals of Dyslexia, 56(1), 103-128.

Fawcett, A. J., Nicolson, R. I., \& Maclagan, F. (2001). Cerebellar tests differentiate between groups of poor readers with and without IQ discrepancy. Journal of Learning Disabilities, 33(2), 119-133.

Fletcher, J. M., Lyon, G. R., Fuchs, L., \& Barnes M. A. (2009).

Oppimisvaikeudet: tunnistamisesta interventioon [Learning disabilities - from identification to intervention]. Unipress.

Frith, U, Wimmer, H., \& Landerl, K. (1998). Differences in phonological recoding in German and English speaking children. Scientific Studies of Reading, 2, 3134.

Goldberg, R.J., Higgins, E.L., Raskind, M.H., \& Herman, K.L. (2003). Predictors of success in individuals with learning disabilities: A qualitative analysis of a 20-year longitudinal study. Learning Disabilities Research and Practice, 18, 222-236.

Hatcher, J., Snowling, M. J., \& Griffiths, Y. M. (2002). Cognitive assessment of dyslexic students in higher education. British Journal of Educational Psychology, 72, 119-133.

Holopainen, L., Ahonen, T., \& Lyytinen, H. (2001) Predicting reading delay in reading achievement in a highly transparent language. Journal of Learning Disabilities, 34(5), 401-414.

Holopainen, L., Kairaluoma, L., Nevala, J., Ahonen T., \& Aro, M. (2004). Lukivaikeuksien seulontamenetelmä nuorille ja aikuisille. [The Finnish dyslexia screening test for youth and adults]. Jyväskylä: Jyväskylän yliopistopaino.

Hudson, R. F., High, L., \& Al Otaiba, S. (2007). Dyslexia and the brain: What does current research tell us? The Reading Teacher, 60(6), 506-515.

Jiménez, J. E., Siegel, L. S., \& Lopez, M. R. (2003). The relationship between IQ and reading disabilities in English-speaking Canadian and Spanish children. Journal of Learning Disabilities, 36(1), 15-23. 
Jiménez, J. E., Siegel, L. O'Shanahan, I., \& Ford L. (2009). The relative roles of IQ and cognitive processes in reading disability. Educational Psychology, 29(1), 27-43.

Kortteinen, H., Närhi, V., \& Ahonen T., (2009). Does IQ matter in adolescents' reading disability? Learning and Individual Differences, 19, 257-261.

Liederman, J., Kantrowitz, L., \& Flannery, K. (2005). Male vulnerability to reading disability is not likely to be a myth: A call for new data. Journal of Learning Disabilities, 38(2), 109-129.

Lyon, G. R., Shaywitz, S. E., \& Shaywitz, B. A., (2003). A definition of dyslexia. Annals of Dylexia, 53, 1-14.

Lyytinen, H., Aro, M., Holopainen, L., Leiwo, M., Lyytinen, P., \& Tolvanen, A. (2005). Children's language development and reading acquisition in a highly transparent language. In R.M. Joshi \& P.G. Aaron (Eds.), Handbook of orthography and literacy, pp. 47-63. London: Lawrence Erlbaum Ass.

McNulty, M.A. (2003). Dyslexia and the life course. Journal of Learning Disability, 36,363-381

Nyman, K. (2007). Varusmiesten johtajavalintojen luotettavuus [The reliability of conscripts' leader training election]. Maanpuolustuskorkeakoulun Käyttäytymistieteiden laitos. Julkaisusarja 1 Nro 1/2007. Helsinki: Edita Prima Oy.

Parkkola, K. (1999). Varusmiespalveluksen keskeytymisen ennakointi. Seurantatutkimus strukturoidun varusmieshaastattelun ja varusmiesseulan ennusarvosta [Predicting failure in the compulsory conscript service. A follow-up study of the predictive value of the structured conscript interview and the conscript screen]. Sotilaslääketieteellinen aikakausilehti [Annales medicinae militaris fenniae], 74(1a), 1180.

Salo, M. (2008). Determinants of military adjustement and attrition during finnish conscript service. National Defence University, Department of Education, Publication Series 2, Research Reports No 21. Helsinki: Edita Prima Oy.

Savolainen, H., Ahonen, T., Aro, M., Tolvanen, A., \& Holopainen, L. (2008). Reading comprehension, word reading and spelling as predictors of school achievement and choice of secondary education. Learning and Instruction, 18, 201-210.

Torgensen, J. K., \& Wagner, R. K. (1998). Alternative diagnostic approaches for specific developmental reading disabilities. Learning Disabilities Research \& Practice, 13(4), 220-232.

Vellutino, F. R., Scanlon, D. M., \& Lyon, G. R. (2000). Differentiating between difficult-to-remediate and readily remediated poor readers. More evidence against the IQachievement discrepancy definition of reading disability. Journal of Learning Disabilities, 33(3), 223-238.

Vellutino, F. R., Fletcher, J. M., Snowling, M. J., \& Scanlon, D. M. (2004). Specific reading disability (dyslexia): What have we learned in the past four decades? Journal of Child Psychology and Psychiatry, 45(1), 2-40.

Wheldall, K. (2010). Do more boys than girls have reading problems? Journal of Learning Disabilities, 43(5), 1-12.

Wilson, A. M., \& Lesaux, N. K. (2001). Persistence of phonological processing deficits in college students with dyslexia who have age-appropriate reading skills. Journal of Learning Disabilities, 34(5), 394-400.

Zeffiro, T., \& Eden, G. (2000). The neural basis of developmental dyslexia. Annals of Dyslexia, 50, 3-30. 